East African Medical Journal Vol. 86 (Supplement) December 2009

PREVALENCE OF IRON DEFICIENCY IN CHILDREN WITH CYANOTIC HEART DISEASE SEEN AT KENYATTA NATIONAL HOSPITAL AND MATER HOSPITAL NAIROBI

M. O. Lang'o, MBChB, MMed (Paed), Paediatrician, Gertrude's Children's Hospital, P. O. Box 42325 - 00100, Nairobi, Kenya, J. N. Githang'a, MBChB, MMed (Path), Senior Lecturer, Department of Pathology and C. A. Yuko-Jowi, MBChB, MMed (Paed), Senior Lecturer, Department of Paediatrics and Child Health, College of Health Sciences, University of Nairobi, P. O. Box 19676 -00202, Nairobi, Kenya

Request for reprints to: Dr. M. O. Lang'o, Gertrude's Children's Hospital, P. O. Box 42325 - 00100, Nairobi, Kenya

\title{
PREVALENCE OF IRON DEFICIENCY IN CHILDREN WITH CYANOTIC HEART DISEASE SEEN AT KENYATTA NATIONAL HOSPITAL AND MATER HOSPITAL NAIROBI
}

\author{
M. O. LANG'O, J. N. GITHANG'A and C. A. YUKO-JOWI
}

\begin{abstract}
Objective: To establish the prevalence of iron deficiency among children with cyanotic heart disease.

Design: Cross-sectional study.

Setting: The study was carried out at Kenyatta National Hospital and Mater Hospital from August to December of 2007. A total of 112 children meeting the eligibility criteria were recruited from the wards and the cardiac clinics.

Subjects: These were children less than 18 years of age, with cyanotic heart disease confirmed on ECHO, presenting at the paediatric cardiac clinic of the two hospitals or admitted in the wards at Kenyatta National Hospital. These were patients who had not undergone surgical correction.

Results: The prevalence of iron deficiency was found to be $16.9 \%$ (95\% CI 9.824.1\%).

Conclusion: There is a high prevalence of iron deficiency among patients with congenital heart disease with cyanosis in the two institutions. Routine screening for iron deficiency is recommended for these children and those found to be deficient should be treated.
\end{abstract}

\section{INTRODUCTION}

Uncorrected congenital cyanotic heart lesions (and some acyanotic lesions which later have reversal of blood flow from right to left with the development of Eisenmenger's complex) keep the body in a state of constant hypoxia. This hypoxia triggers a physiological increase in erythropoietin release leading to stimulation of the bone marrow to produce more red cells in an effort to increase the body's oxygen carrying capacity, so as to improve oxygen delivery to the tissues. With persisting right to left shunt, the arterial oxygen tensions remain perpetually low and so the production of more and more red cells goes unabated leading to polycythemia. This seemingly noble physiological response eventually leads to depletion of iron stores.

In these patients, the total haemoglobin is normal, high or slightly reduced compared to aged-matched normal individuals without cyanosis. However, the $\mathrm{MCV}, \mathrm{MCH}$ and serum ferritin are usually comparatively lower than their peers as shown by
Cemile et al (1) - a phenomenon known as relative anaemia. Irrespective of cause, iron deficiency leads to a significant increase in whole blood viscosity in erythrocytotic patients, and the viscous effect rises with decreasing erythrocyte mean corpuscular haemoglobin (2).

Patients with iron deficiency will have higher morbidity rates presenting with symptoms of hyperviscosity such as cerebrovascular accidents, cyanotic spells, anorexia, exercise intolerance, poor appetite, poor weight gain, irritability and poor mental development. Treatment of iron deficiency has been shown to reverse all these symptoms. Gaiha et al (3) showed that hyperviscosity symptoms occurred at a lower PCV level (0.52-0.58) among cyanotic patients withirondeficiency as compared to those who wereiron sufficient where symptoms occurred at the mean PCV of 0.68 . Among the iron deficient group, hyper cyanotic symptoms were relieved with iron supplements, and this symptomatic relief was accompanied by an average haemoglobin rise of $2.1 \mathrm{~g} / \mathrm{dl}$ (3). Similar effects were demonstrated by Perfloff et al (4). 


\section{MATERIALS AND METHODS}

Study population: These were children less than 18 years of age with ECHO confirmed cyanotic heart disease who had not undergone corrective surgery, presenting at the paediatric cardiac clinic of Kenyatta and Mater Hospitals or admitted in the wards at Kenyatta National Hospital. Those already on iron supplements were excluded from the study.

Samplesize calculation: The sample size was calculated using Fischer's method.

Sampling: Patients meeting the eligibility criteria were consecutively recruited from the two hospitals between 8 and 3 pm, till the desired sample size was attained.

Study duration: This study was carried out over five months (August 2007 to December 2007).

Study design: This was a cross-sectional study.

Procedures: Patients were identified and recruited into the study once consent was obtained. Body temperature was taken; height and length were measured in centimeters using a stadiometer. Weight was taken using a step-on weighing scale, or an infant weighing scale for infants. Date of birth, sex and residence was recorded on the questionnaire. A history and physical examination was used to help exclude inflammatory disease which are known to affect ferritin levels.

About $2 \mathrm{ml}$ of venous blood was drawn using a $5 c c$ syringe and divided equally into a plain bottle and EDTA bottle. The complete blood count was done using the electronic cell counter - Cell-Dyn 1300. Ferritin levels were performed using a semi automated process using Humalyzer 2000.

\section{Study definitions}

(i) Iron deficiency: Depletion of the body's iron stores as evidenced by low ferritin levels that are below the lower limit of the age specific reference range (5). In this study, ferritin was the gold standard for measuring iron stores. (ii) Low MCV and low MCH was defined as an MCV or $\mathrm{MCH}$ values that is below the lower limit of the age specific reference range.

Data analysis: The study population was described in terms of their demographic and clinical characteristics using means, medians and proportions. Prevalence of iron deficiency was calculated as proportion of children with ferritin values below -2SD of the reference mean. Children with iron deficiency were compared to those without to determine associated factors. Chi-square tests and t-test were used to determine factors with significant associations. Data was analysed using the Statistical Package for Social Sciences software (SSPS).

Ethical considerations: The hospitals' ethics committees approved the study. Written consent was obtained from guardians for each participant after detailed explanation.

\section{RESULTS}

One hundred and twelve children were recruited into the study. Their ages ranged from one month to 17 years, with a median age of four years and five months. The mean age was 5 years 10 months. Males were 59 while 53 were female, giving a male to female ratio of 1:1. The commonest heart lesion encountered was Tetralogy of Fallot (54\%).

Fifty nine out of 112 patients $(52.6 \%)$ were below five years of age, while 53 out of $112(47.3 \%)$ were older than five years. The nutritional status was analysed based on the CDC 2000 guidelines. Twenty (17.9\%) were classified as moderately stunted, while 25(22.3\%) were severely stunted. Moderate wasting was seen in $17(15.2 \%)$ of the study population while $23(20.5 \%)$ were severely wasted (Table 1).

Heart lesions were divided into those with predominantly left to right shunt and those with predominantly right to left shunt. Complex lesions seen in this study included dextrocardia and a host of other complicated cardiac anatomy lesions. The most frequently encountered heart lesion was Tetralogy of Fallot followed by tricuspid atresia (Table 2). 
Table 1

Summary of the characteristics of the study population $(n=112)$

\begin{tabular}{llcc}
\hline Parameter & Category & No. & $(\%)$ \\
\hline Age (years) & $<1$ & 20 & 17.8 \\
& $>1-5$ & 39 & 34.8 \\
& $>5-12$ & 35 & 31.3 \\
\multirow{3}{*}{ Sex } & $>12$ & 18 & 16.1 \\
\multirow{3}{*}{ Nutritional status } & Male & 59 & 52 \\
& Female & 53 & 48 \\
& Normal and mild stunting & 67 & 59.8 \\
& Moderately stunted & 20 & 17.9 \\
& Severely stunted & 25 & 22.3 \\
& Normal and mild wasting & 72 & 64.3 \\
& Moderate wasting & 17 & 15.2 \\
& Severe wasting & 23 & 20.5 \\
\hline
\end{tabular}

Table 2

Frequency of encountered heart lesions ( $n=112)$

\begin{tabular}{lcc}
\hline Lesion & No. (\%) \\
\hline Predominantly right to left shunt & & \\
$\quad$ Tetralogy of fallot & 61 & 54 \\
Tricuspid atresia & 9 & 8 \\
Pulmonary atresia with VSD & 6 & 5.3 \\
Double outlet right ventricle & 4 & 3.5 \\
$\quad$ Critical pulmonary stenosis & 3 & 2.6 \\
$\begin{array}{l}\text { Predominantly left to right shunt } \\
\text { Truncus arteriosus }\end{array}$ & 2 & \\
$\quad$ Transposition of great arteries & 5 & 4.4 \\
Eisenmengers and other complex & & \\
heart lesions & 22 & 19 \\
\hline
\end{tabular}

Eighteen out of 106 patients had ferritin levels below the lower limit of their age specific reference ranges giving an iron deficiency prevalence of $16.9 \%$ (CI 9.8-24.1\%). Half the study population had MCV and $\mathrm{MCH}$ values below the age specific reference ranges (50.5\% for low MCV and 50\% for low $\mathrm{MCH}$ ). Findings of microcy tic hypochromic cells were seen in 33 out of 106 patients giving a prevalence of $31.1 \%$ (Table 3).

There was no statistically significant difference in the occurrence of any of the haematological derangements between the predominantly left to right shunting lesions and the predominantly right to left shunting lesions (Table 4).

Table 3

Summary of the haematological parameters

\begin{tabular}{llllllll}
\hline Parameter & Mean (95\% CI) & Median & Inter- Quartile & \multicolumn{2}{l}{ Normal and } & \multicolumn{2}{l}{ Derangements } \\
& & & range & \multicolumn{2}{l}{$\begin{array}{l}\text { acceptable values } \\
\text { of interest }\end{array}$} \\
& & & & No. $(\%)$ & No. & $(\%)$ \\
\hline Serum ferritin & $48.9(40.5-57.3)$ & 39 & 61.25 & $88 / 106$ & 83.1 & $18 / 106$ & 16.9 \\
MCV & $76.3(74.2-78.4)$ & 77 & 17 & $51 / 103$ & 49.5 & $52 / 103$ & 50.5 \\
MCH & $25.8(24.9-26.8)$ & 25.45 & 7.17 & $51 / 102$ & 50 & $51 / 102$ & 50 \\
$\begin{array}{l}\text { Hypochromic } \\
\text { microcytic cells }\end{array}$ & & & & & & & \\
\hline
\end{tabular}


In this study all iron deficient patients fell in the group of children aged less than five years of age. This was statistically significant $(p=0.000)$. The other significant factor associated with iron deficiency was stunting, specifically, severe stunting. There was a five fold increased likelihood of having iron deficiency with the presence of severe stunting (odds ratio 4.88 [95\% CI 1.48-16.2], $\mathrm{p}=0.005)$. No statistically significant relationship was noted between iron deficiency and $\operatorname{sex}(p=0.301)$ and between iron deficiency and wasting $(\mathrm{p}=0.673)$ (Table 5).

\section{DISCUSSION}

The overall prevalence of iron deficiency in this study was $16.9 \%$, which is almost similar to what was found in the study done in India by Gaiha et al (3) where they reported a prevalence of $18.2 \%$ and much higher than the prevalence of $7 \%$ reported by Murila et al (6) in Kenya who looked at a generally healthy population of children less than 5 years of age. Interestingly, in our study all the 18 patients found to be iron deficient were below five years of

Table 4

Influence of the type of heart lesion on the haematological derangements

\begin{tabular}{|c|c|c|c|c|c|c|c|}
\hline Parameter & $\begin{array}{l}\text { CCHD } \\
\text { Left to } \\
\text { No. } \\
\end{array}$ & $\begin{array}{l}\text { predominantly } \\
\text { right shunt } \\
(\%)\end{array}$ & $\begin{array}{l}\mathrm{CCH} \\
\text { Righ } \\
\text { No. }\end{array}$ & $\begin{array}{l}\text { D predominantly } \\
\text { to left shunt } \\
(\%)\end{array}$ & OR & $95 \%$ CI) & P-value \\
\hline Serum ferritin & & & & & & & \\
\hline $\begin{array}{l}\text { Iron deficiency } \\
\text { Rbc indicators }\end{array}$ & $12 / 70$ & 14.6 & $2 / 5$ & 28.6 & 0.43 & $0.06-3.63$ & 0.302 \\
\hline Low MCV & $36 / 82$ & 43.9 & $2 / 7$ & 28.6 & 1.96 & $0.31-15.57$ & 0.690 \\
\hline Low $\mathrm{MCH}$ & $22 / 82$ & 26.8 & $1 / 7$ & 14.3 & 2.20 & $0.24-51.26$ & 0.690 \\
\hline $\begin{array}{l}\text { PBF-Microcytic } \\
\text { hypochromic cells }\end{array}$ & $28 / 82$ & 43.1 & $1 / 7$ & 14.3 & 3.11 & $0.34-71.99$ & 0.420 \\
\hline
\end{tabular}

Table 5

Non-cardiac correlates of iron deficiency

\begin{tabular}{|c|c|c|c|c|c|c|c|}
\hline \multirow{2}{*}{$\begin{array}{l}\text { Parameter } \\
\text { No. } \quad(\%)\end{array}$} & \multicolumn{2}{|c|}{ Iron deficiency } & \multirow{2}{*}{\multicolumn{2}{|c|}{ No iron deficiency }} & \multirow[t]{2}{*}{ OR } & \multirow[t]{2}{*}{$95 \% \mathrm{CI}$} & \multirow[t]{2}{*}{ P-value } \\
\hline & No. & $(\%)$ & & & & & \\
\hline \multicolumn{8}{|l|}{ Age } \\
\hline$<60$ months & $18 / 18$ & 100 & $41 / 94$ & 43.6 & - & - & 0.000 \\
\hline$\geq 60$ months & $0 / 18$ & 0 & $53 / 94$ & 56.4 & & & \\
\hline \multicolumn{8}{|l|}{ Sex } \\
\hline Male & $11 / 18$ & 61.1 & $48 / 94$ & 51 & 1.5 & $0.49-4.76$ & 0.301 \\
\hline Female & $7 / 18$ & 38.9 & $46 / 94$ & 49 & & & \\
\hline \multicolumn{8}{|l|}{$\begin{array}{l}\text { Nutrition status } \\
\text { stunting }\end{array}$} \\
\hline Severe & $9 / 18$ & 50 & $16 / 94$ & 17 & 4.88 & $1.48-16.2$ & 0.005 \\
\hline Moderate & $1 / 18$ & 5.5 & $19 / 94$ & 20.2 & 0.22 & $0.01-1.85$ & 0.19 \\
\hline Mild to normal & $8 / 18$ & 44.5 & $59 / 94$ & 62.8 & 0.47 & $0.15-1.46$ & 0.23 \\
\hline \multicolumn{8}{|l|}{ Wasting } \\
\hline Severe & $5 / 18$ & 27.8 & $32 / 93$ & 34.4 & 0.73 & $0.21-2.48$ & 0.78 \\
\hline Moderate & $6 / 18$ & 33.3 & $22 / 93$ & 23.6 & 1.61 & $0.47-5.38$ & 0.386 \\
\hline Mild to normal & $7 / 18$ & 38.9 & $39 / 93$ & 42.0 & 0.88 & $0.28-2.75$ & 0.98 \\
\hline
\end{tabular}


age. Drossos et al (7) from Italy in 1981 examining a total of 38 cyanotic heart disease children, found an iron deficiency prevalence of $12.5 \%$ in children 6 to 12 years of age. Similarly, in the same study, children less than five years still contributed the bulk of the iron deficiency group with a prevalence of $37.5 \%$.

Ferritin measurements as indicator of iron status are prone to giving false negative results as they are affected by many factors causing inflammation including infection. This leads to a falsely elevated ferritin level, thus the false negatives. In our local set up, with high prevalence of infectious diseases, it is possible that our ferritin assays could have underestimated the prevalence of iron depletion.

From this study, we found that $40.1 \%$ (45 out of 112) children were stunted. This is much higher than the national figure of 30\% reported in the Kenya Demographic and Health Survey (KHDS) 2003. Out of these, $22.3 \%$ were severely stunted while $17.9 \%$ were classified as moderately stunted. Wasting was seen in $35.7 \%$ (40 out of 112 ) of our study population, a figure much higher than the national figure of $6 \%$ reported in the KHDS 2003. Severe wasting was seen in 20.5\% of the study population while moderate wasting was seen in $15.2 \%$. This was however an expected finding given the burden of the heart disease on its own is expected to interfere with growth and general well being and food intake.

In conclusion, there is a high prevalence of $16.9 \%$ of iron deficiency in children with cyanoticheart disease attending the cardiac clinics at Kenyatta National Hospital and Mater Hospital.
We recomend that, children with cyanotic heart disease should routinely be screened for iron deficiency, using a combination of blood picture and ferritin levels and those found deficient should be treated accordingly.

\section{REFERENCES}

1. Cemile, B. O., Tansu, S., Betul, T., et al. Diagnosing iron deficiency in cyanotic heart disease. Indian J. Pediatrics. 2003; 70: 29-31.

2. Hutton, R.D. The effect of iron deficiency on whole blood viscosity in polycythaemic patients. Brit. J. Haematol. 1979; 43:191-199.

3. Gaiha, M., Sethi, H. and Sudha, R. A clinicohematological study of iron deficiency anaemia and its correlation with hyperviscosity symptoms in cyanotic congenital heart disease. Indian Heart J. 1993: 45: 53-55.

4. Perloff, J. K., Rosove, M. H. and Child, S.J. Adults with cyanotic congenital heart disease: Hematologic management. Annals Inter. Med. 1988;109: 406-413.

5. Behrman, R.E., Kliegman, R.M. and Jenson, H.B. Nelson Text Book of Pediatrics. W B Saunders Company. Philadelphia. 17 ${ }^{\text {th }}$ Edition 2004; 2406.

6. Murila, F.V., Macharia, W.M. and Wafula, E.M. Iron deficiency anaemia in children of a peri-urban health facility. East Afr. Med. J. 1999; 76: 520-523.

7. Drossos, C., Thanapoulos, B., Papadimitrou, A., et al. Incidence of anaemia in congenital heart disease. Med. Surg. Pediatrics. 1981; 3: 309-312. 